\title{
The Urgency of Inclusive Education in Realizing Sustainable Development
}

\author{
Ari Wahyudi ${ }^{1}$, Muhammad Turhan Yani ${ }^{2}$, Ajeng Sukma Mawarni DF ${ }^{3}$ \\ \{ariwahyudi@unesa.ac.id ${ }^{1}$, muhammadturhan@unesa.ac.id ${ }^{2}$, ajengsukma.2019@student.uny.ac.id ${ }^{3}$ \} \\ ${ }^{1}$ Department of Sociology, Universitas Negeri Surabaya, Indonesia \\ ${ }^{2}$ Department of Pancasila and Civic Education, Universitas Negeri Surabaya, Indonesia \\ ${ }^{3}$ Department of Special Education, Universitas Negeri Surabaya, Indonesia
}

\begin{abstract}
One of the sustainable development goals is to ensure that education is inclusive and has equal quality. The actual manifestation is the policy of the Indonesian government to encourage the realization of a massive inclusive school. The problem revealed in this research is how substantial is the urgency of inclusive education in realizing sustainable development. Though literature and in-depth field studies, the research findings are; (1) Inclusive education in Indonesia, at the level of implementation, still requires adequately trained teachers, (2) Inclusive education is a tangible manifestation of education for all, originating from human rights.
\end{abstract}

Keywords; Inclusive education, Sustainable development, Education for all.

\section{Introduction}

The two perspectives on education services for people with disabilities in Indonesia continues to move to the pros and cons. Segregation of services by providing a separate place for children with disabilities and the community of normal children is a rejection of disabled people as part of social life. According to Freire, this condition is an act of dehumanization, means that there is an ambivalence of meaning, namely controlling the majority and the minority. It happened because the majority are made helpless and submerged in the culture of silence [1]. While the minority becomes inhuman because they force something to others. The rise of the deterioration of disabled people from this conditions began when there was an attempt by blind people, who were originally Special Schools (SLB) for blind people in Bandung in the 1960s that only served up to the Junior Secondary Level (SLTP), trying to break into High School (SMA). At first, there was a lot of rejection from the school, but slowly their attitude has changed. In 1970, the government issued a decree of the minister of education about integration education [2].

This integration of education does not last long because it still depends on the project. Besides, a further struggle for people with disabilities in education must be served as a whole in the form of inclusive education. The implementation began with the corporation between the National Education Ministry and the Norwegian government which was under the management of Braillo Norway. Furthermore, this inclusive education will lead to humanist education. The concept developed by inclusive education is an ideology, system and or strategy in the implementation of education that children with special needs should have the same educational services and learning environment with other children in good quality and based on their needs. The big issue of inclusive education is getting stronger when Salamanca's statement (1994) provides a discourse that all educational services for people 
with disabilities as long as they can achieve maximum life for academic and non-academic needs, must be served with a regular environment.

Therefore, to show the enthusiasm of the implementation of humanistic education for people with disabilities as a manifestation of the Sustainable Development Goals (SDGs), it needs a study about (1) how relevance inclusive education with humanist education, (2) how was the implementation of liberating inclusive education. The purpose of this research is to describe the relevance of inclusive education with humanist education and the application of liberating inclusive education.

\section{Method}

This study used Paulo Freire's perspective on liberating education to examine the implementation of inclusive education in Indonesia. One case of organizing an inclusive school that serves special classes and inclusive classes is a particular concern in Freire's perspective. The target of this study is inclusive schools in Indonesia. This school runs an inclusive school with two services, namely special class services and inclusive class services. Data collection is done by field observation to see directly the relationship between the implementation of inclusive education and humanist education, and inclusive education that liberates. Data obtained on the field were analyzed by flow analysis models and directly narrated as findings.

\section{Result and Discussion}

Data from the Indonesian Ministry of Social Affairs in 2010 showed that children with disabilities who had recently received education services in special schools or inclusive schools had only reached 85,737 (25.92\%). It means that there are 245,027 (74.08\%) children with disabilities have not received education services yet. The reality of implementing inclusive education in Indonesia, which is only $25.92 \%$ is still ambivalent. On the one hand, accepting children with disabilities in public schools is a form of respect for human rights. Means that the rights of persons with disabilities are respected as human nature and must be treated the same as others. However, forcing children to be served in public schools, within the limits of both their children and their accessibility, does not respect the real condition of children with disabilities who should receive special services in special schools. The reality of organizing such inclusive education can be analyzed in Freire's perspective as a humanizing education service and a liberating education service. These following is an analysis of the implementation of inclusive education in Indonesia based on Freire's perspective.

\section{a. Inclusion Education and Humanization in Indonesia}

Legal products aimed to transform disabled-friendly education have been produced in Indonesia. Legal products relating to this have been dozens of numbers ranging from the constitution to the authorized ministerial regulations. However, the community and government still treat them unfairly.

That condition is in line with Freire's criticism that the form of suppression to the minorities done by the authorities (government) is still real. This criticism is suitable to be used to analyze the education problems of people with disabilities in Indonesia. Freire idea is 
different from Indonesia's background so his way of thinking can be adopted to analyze the overall education problem including disability problems [3].

The form of disabled education services that are separate from normal children is kind of dehumanization because they deny the existence of disabled people as a part of society in general. The practices of disabled utilization as government commodities or certain institutions are a real form of suppression of human dignity. Instead of raising human dignity by providing opportunities for having equal activities with normal children, it shows the different line because of the special classes on inclusive education services. According to Freire, the real condition in Indonesia are said to be the conditions for mastering the realities of life of disabled people have become silent.

Freire's concept of making humanization on inclusive education is by giving them learning to know the full concept of themselves. It means that people with disabilities must be capable, listen to their hearts, not from other voices, including the voice of the educators. The implication in this context is not because of the protests over unfair treatment of disabled people, and also not a strategy to withstand intervention from outside authorities. The silent culture occurs is because of silence. The silent culture is the sense of not knowing what happened. The conditions occur when someone not feeling like a disabled. Therefore, according to Freire, to master the reality of life, including realizing the disability, language must be mastered. Furthermore, to get disable people out of silence, we need to teach them to increase their capability of doing self-introspection, self-correction, and not following other people's patterns including the teacher's mindset. This real condition is said by Freire as an effort to free themselves from oppression.

\section{b. Inclusive Education that Liberates}

Inclusion education puts individuals based on their dignity as human beings who must live together. The concept of inclusion is in line with Freire idea of offering problem-posing education as a way of raising silent people's awareness. It needs a kind of learning styles that are innovative and provide opportunities for students to be able to know exactly who they are. The role of the teacher is as a facilitator, tutor, motivator, even as a learning provocateur. These contexts need to be built for students because they will face the new era of education full of technology. Besides, the disruption era must be faced with digital technology transfer. In this 4.0 industrial revolution, students are required to do, find, and initiated by themselves. This also requires teachers to innovate their lags by developing all their potential.

Furthermore, Freire also criticizes Banking Concept of Education [4], namely students are seen as objects to accommodate all the knowledge given by the teacher. So the concept of a good education is when teachers can provide a lot of knowledge to children. The concept of a good teacher is when the teacher can give as much knowledge to students. A good teacher should be able to put something in a "pot", pour it out with full of material given by the teacher. The implication is, students only memorize everything that is told by their teacher without understanding. In this case, students are being the objects, not the subjects. The education process is like a horse's goggles, students did what they saw in the future, not creative, and did not try to develop their hidden potential, just like what Freire said about "Banking Concept of Education". It is called Banking Concept of Education because the teacher only did a transfer of knowledge like puts water in an empty bottle. Students must be demanded subordinates with conventional teaching systems. Students are just a place to keep messages from all what the lecturers say. The teacher's role is very dominant, the impression of the teacher as a powerful teacher always appear in learning activities. Banking Concept of 
Education will be dominated by suppressors to suppress fellow human who needs a better life [5]. Paulo Freire rejection on Banking Concept of Education shows that it comes up from his understanding of humans. Humans must be seen as active and productive beings. He refuses a perspective said that humans as passive beings do not need to make choices on their responsibility regarding education [6].

Education that liberates for disable people must refer to the education style based on Freire, namely problem posing as an alternative education that comes up from his conception of humans [7]. Humans referred here are who have authority as subjects of education not objects of education. They are used as the subject focus of problem posing education. Groups of people who can adapt to their surroundings and will no longer isolate themselves from the world and reality, humans who can merge themselves and be part of the world [8]. This kind of reality must be implemented for the students to raise their awareness. That construction of education must be based on the knowledge that humans have the potential to be creative and be free from cultural, economic and political oppression [9]. The awareness grows from the struggle over the reality faced and produce a critical behavior in students.

The concept of liberating inclusive education will build the concept of human awareness [10]. Awareness that built as a basis is indicated by the depth of interpreting the problems, religion in the discussion, being able to accept and reject, and having dialogical dialogues. At this level, people can reflect and see causal relations. This condition, according to Freire's concept, occupies transitive critical awareness, means that education will succeed when it grows critical awareness, so the creative and innovative thinking always grows continuously. Educational power controllers must be aware and encourage others to join coloring inclusive education services that humanist. Those are intransitive awareness, semi-intransitive or magical awareness, and naive awareness. In such a learning process, the teacher and student contradictions (the differences between teacher as the source of all knowledge and students who do not know anything) do not exist. Students are not seen and placed as objects that must be taught and received knowledge. Also, the role of the teacher does not as an educator. Teachers and students are both learning from the problems faced. Teachers and students together as subjects in solving problems. Besides that, the teacher acts and roles as a coordinator that facilitates dialogical conversation. They are being a friend to solve problems. Meanwhile, students are active participants in the dialogue. The materials in the learning process are not taken from several standard formulas in the textbook but several problems. That problem becomes the topic of dialogical discussion that based on the reality of life experienced by students in their daily life, for instance in eradicating illiteracy. First, students and teachers are together finding and absorbing key themes of student problem boundary situation. These key themes will be discussed regarding the various connection and their impacts. Besides, students will learn the situation and say it with their language. This is what Freire mentioned, the world with its language. The words then spelled and written by them. This process is increasingly being developed so that students can compile words from their own.

Freire's thought about the awareness to foster humanist inclusion services must change the way teacher thinking related to their relationship with students [11]. The main job of the teacher is making students as the education subject, not the object. The subject of education means students will act as authority holders related to their academic development in each study group. The path that must be taken is to encourage students to develop critical awareness as well as to encourage social structure transformation for oppressive groups in the environment. This act must be done because human awareness is dialectically cycled between himself and the environment. Students have the potential to grow and develop, even the 
environment and the social structures are also determining this potential. For this reason, the dual function mobility between emancipation and transcendence of the level of awareness must be involved to create a humanistic relationship. The principle of learning can be achieved when the process has a relation between teacher and student (subject matter). As Freire suggestion that the teacher not only as an educator, but also as counselor, coach, manager classes, learners, and even become cultural workers [12]. The role of the teacher in the future is getting harder, the teacher who likes to perform in front of the class applying lecture method will be eliminated in the learning process. It has been announced that the role of the teacher in preparing for the 2045 gold generation will be heavier. Nowadays, teachers should be able to prepare students to master $21 \mathrm{st}$-century skills namely critical and analytical thinking, creative and innovative, communicative, and collaborative. The teacher's duty in preparing the golden generation are (1) facilitator, teacher is able to help students in the learning process, (2) goalkeeper, teacher helps students to be able to filter negative influences, (3) educator, teacher is able to convey subjects to be understood by students, (4) Catalysts, teacher is able to identify, explore and optimize the students' potential and (5) Liaison, teacher is able to connect students with diverse learning resources both inside and outside the school.

The change of learning paradigm in the 21 st-century and the industrial era 4.0 will have an impact on teacher performance in Indonesia. The characteristics of 21 st-century learning are followed by a learning model. Learning characteristics and learning models can be identified as follows; (1) Characteristics of accessible information anywhere and at any time will require a learning model to encourage students to find out information from various sources of observation, rather than being told; (2) Characteristics of computation which encourage a faster performance because of the use of machine will be required to be able to formulate the problems (questioning) and not only solve the problems (answering); (3) Automation characteristics that will be able to reach all routine work, will require a learning model that is directed to do analytical thinking (decision making), which is not mechanistic (routine) thinking; (4) Characteristics of communication from anywhere and everywhere, will require learning models that emphasize the importance of collaboration in solving the problems. This condition will lead the teachers to be able to answer the future challenges. Teachers' characteristics that have been expected are (1) adaptation to the changing times, (2) a lifelong learner, (3) pattern and proximity, which is not controlling behavior [13].

Education that can be understood as cultural action for liberation is education that cannot be limited to its function only for the learning area in the school. The function must be expanded to create a more democratic public life. As stated by Freire, "reading a word cannot be separated from reading the world and speaking must be related to transforming reality." Thus, there must be a kind of contextualization of classroom learning. The text taught in class must be related to real life. In other words, there must be a dialectic between text and context, text and reality.

\section{Conclusion}

Humanist inclusive education will be achieved when the key points in bringing together different groups can be implemented. The concrete step is to condition the two groups together and should be autonomous subjects and be able to make sharp criticisms of the reality of existence. Both must be intended to develop critical awareness and transform unjust social structures. The foundation of legal sources must have been very strong through our laws and regulations, such as Law No. 20 of the National Education System Law in 2003 also mandated 
to provide equal treatment in education services for persons with disabilities in the form of inclusive education. Therefore, it is time for us to pay attention to the future of these two groups. Our education should be on their side, not serving the interests of the dominant community [14]. The expected outcome of education is Humane People, who do not only respect themselves but also has a desire and awareness to treat others with respect and dignity. Therefore, to create humane people the Humanistic Approach must be developed [15].

\section{Acknowledgments}

The author wishes to thank the Head of Surabaya State University and Head of Faculty of Social and Law for providing a facility to join International Conference in ICESI 2019 UNNES.

\section{References}

[1] P. Freire, Pendidikan Pembebasan. Jakarta: LP3S, 2000.

[2] D. Tarsidi, "The 8th International Congress on Including Children with Disabilities in the Community," in The implementation of Inclusive Education in Indonesia, 2003.

[3] M. Manggeng, "Pendidikan Yang Membebaskan Menurut Paulo Freire dan Relevansinya dalam Konteks IndonesiaNo Title.” artikel webside, 2009.

[4] P. Freire, Pendidikan Pembebasan. Jakarta: LP3S.

[5] D. Tarsidi, "Pendidikan inklusif sebagai satu inovasi kependidikan untuk mewujudkan pendidikan untuk semua," UPI Bandung, 2002.

[6] Subagi, "Kritik Atas: Konsientisasi dan Pendidikan. Teropong Paulo Freire dan Ivan Illich", dalam Martin Sardy (ed.)," 2012, pp. 104-105.

[7] P. Freire, Cultural Action For Freedom. Baltimore: Penguin Book, 1970.

[8] M. Sutrisno, Pendidikan Pemerdekaan. Jakarta: Penerbit Obor, 1995.

[9] D. S. Schipani, "Religious Education Encounters Liberation Theology," Alabama: Religious Education Press, 1988, p. 38.

[10] Budiyanto, "Implementasi pendidikan inklusif di Indonesia berdasarkan budaya local," UPI Bandung, 2005.

[11] P. Coleridge, Pembebasan dan Pembangunan: Perjuangan Penyandang Cacat di Negara-negara Berkembang. Yogjakarta: Pustaka Pelajar.

[12] S. J. David, Inklusi. Sekolah Ramah untuk Semua. Bandung: Penerbit Nusa, 2006.

[13] S. R. Pantjastuti, "Milestone 100 tahun menuju Generasi emas," 2019.

[14] M. A. Nuryatno, "Refleksi Pendidikan Bersama Paulo Freire.,"Wesbsite Kompas, 2010 .

[15] D. Jatman, Sekitar Masalah Kebudayaan. Bandung: Penerbit Alumni, 1995. 